ORIGINAL ARTICLE

\section{Sirolimus and Secondary Skin-Cancer Prevention in Kidney Transplantation}

\author{
Sylvie Euvrard, M.D., Emmanuel Morelon, M.D., Ph.D., \\ Lionel Rostaing, M.D., Ph.D., Eric Goffin, M.D., Anabelle Brocard, M.D., \\ Isabelle Tromme, M.D., Nilufer Broeders, M.D., \\ Veronique del Marmol, M.D., Ph.D., Valérie Chatelet, M.D., \\ Anne Dompmartin, M.D., Ph.D., Michèle Kessler, M.D., Andreas L. Serra, M.D., \\ Günther F.L. Hofbauer, M.D., Claire Pouteil-Noble, M.D., Ph.D., \\ Josep M. Campistol, M.D., Ph.D., Jean Kanitakis, M.D., Adeline S. Roux, M.Sc., \\ Evelyne Decullier, Ph.D., and Jacques Dantal, M.D., Ph.D., \\ for the TUMORAPA Study Group*
}

ABSTRACT

\section{BACKGROUND}

Transplant recipients in whom cutaneous squamous-cell carcinomas develop are at high risk for multiple subsequent skin cancers. Whether sirolimus is useful in the prevention of secondary skin cancer has not been assessed.

\section{METHODS}

In this multicenter trial, we randomly assigned transplant recipients who were taking calcineurin inhibitors and had at least one cutaneous squamous-cell carcinoma either to receive sirolimus as a substitute for calcineurin inhibitors (in 64 patients) or to maintain their initial treatment (in 56). The primary end point was survival free of squamous-cell carcinoma at 2 years. Secondary end points included the time until the onset of new squamous-cell carcinomas, occurrence of other skin tumors, graft function, and problems with sirolimus.

\section{RESULTS}

Survival free of cutaneous squamous-cell carcinoma was significantly longer in the sirolimus group than in the calcineurin-inhibitor group. Overall, new squamous-cell carcinomas developed in 14 patients (22\%) in the sirolimus group (6 after withdrawal of sirolimus) and in $22(39 \%)$ in the calcineurin-inhibitor group (median time until onset, 15 vs. 7 months; $\mathrm{P}=0.02$ ), with a relative risk in the sirolimus group of 0.56 ( $95 \%$ confidence interval, 0.32 to 0.98 ). There were 60 serious adverse events in the sirolimus group, as compared with 14 such events in the calcineurininhibitor group (average, 0.938 vs. 0.250 ). There were twice as many serious adverse events in patients who had been converted to sirolimus with rapid protocols as in those with progressive protocols. In the sirolimus group, $23 \%$ of patients discontinued the drug because of adverse events. Graft function remained stable in the two study groups.

\section{CONCLUSIONS}

Switching from calcineurin inhibitors to sirolimus had an antitumoral effect among kidney-transplant recipients with previous squamous-cell carcinoma. These observations may have implications concerning immunosuppressive treatment of patients with cutaneous squamous-cell carcinomas. (Funded by Hospices Civils de Lyon and others; TUMORAPA ClinicalTrials.gov number, NCT00133887.)
The authors' affiliations are listed in the Appendix. Address reprint requests to Dr. Euvrard at the Department of Dermatology, Hospices Civils de Lyon, Edouard Herriot Hospital Group, 5 Place d'Arsonval, 69437 Lyon CEDEX 03, France, or at sylvie.euvrard@numericable.fr.

*Members of the Efficacy of Rapamycin in Secondary Prevention of Skin Cancers in Kidney Transplant Recipients (TUMORAPA) study group are listed in the Supplementary Appendix, available at NEJM.org.

N Engl J Med 2012;367:329-39. DOI: 10.1056/NEJMoal204166 Copyright (c) 2012 Massachusetts Medical Society. 
KIN CANCERS AFFECT MORE THAN HALF of organ-transplant recipients during their long-term course. ${ }^{1}$ Several studies have shown that after a first cutaneous squamous-cell carcinoma, multiple subsequent skin cancers develop in 60 to $80 \%$ of kidney-transplant recipients within 3 years. ${ }^{2,3}$ Transplant recipients share common risk factors with the nonimmunosuppressed population, ${ }^{4}$ but the specific tumor burden of such patients is linked to the immunosuppressive medications used.5,6 A decrease in cutaneous carcinogenesis after the reduction of immunosuppression has been reported. ${ }^{7}$ Consequently, changes in immunosuppression are frequently made in patients with skin cancer, although there is currently no consensus on the level of morbidity at which this decision is justified. ${ }^{8}$ Cutaneous squamous-cell carcinoma appears to be one of the most appropriate markers for initiating a change in immunosuppressive medication for organ-transplant recipients and subsequently for assessing the effect of such changes on carcinogenesis according to skin-tumor counts.

Skin cancers result from both a decrease in immunosurveillance and drug-specific properties. Calcineurin inhibitors (cyclosporine and tacrolimus) may enhance tumor development through mechanisms independent of host immunity. ${ }^{9-12}$ In contrast, inhibitors of the mammalian target of rapamycin (mTOR), including sirolimus (Rapamune, Pfizer) and everolimus, are newer immunosuppressants that have antineoplastic properties. ${ }^{13,14}$ A few studies have reported a lower rate of skin cancer in transplant recipients who were treated with sirolimus than in those treated with calcineurin inhibitors (with either first-time therapy $^{15,16}$ or after switching $\left.{ }^{17,18}\right)$, but data focusing on the effect of sirolimus on skin carcinomas are still limited. ${ }^{19,20}$ The aim of our study, called the Efficacy of Rapamycin in Secondary Prevention of Skin Cancers in Kidney Transplant Recipients (TUMORAPA), was to assess, in a large cohort, the efficacy of sirolimus for the secondary prevention of skin cancers in kidney-transplant recipients receiving calcineurin inhibitors.

\section{METHODS}

\section{ELIGIBILITY}

Kidney-transplant recipients with stable kidney function who were receiving calcineurin inhibitors and had at least one invasive post-transplant cutaneous squamous-cell carcinoma after transplantation were eligible to participate. (Patients with in situ lesions, such as Bowen's disease and premalignant keratosis, or metastatic cutaneous squamous-cell carcinomas were not considered.) The major exclusion criteria were multiorgan transplantations, a history of organ rejection during the past 6 months, poor graft function (estimated glomerular filtration rate, $<30 \mathrm{ml}$ per minute, according to the Cockcroft-Gault formula; or 24-hour protein excretion of $>1 \mathrm{~g}$ ), uncontrolled hyperlipidemia, hematologic or hepatic disorders, and retinoid treatment. The limits on baseline immunosuppressant doses were as follows: glucocorticoids, $10 \mathrm{mg}$ or less per day; azathioprine, $1 \mathrm{mg}$ or less per kilogram of body weight per day; mycophenolate mofetil, $1.5 \mathrm{~g}$ or less per day; and target cyclosporine and tacrolimus blood trough levels, 75 to 125 ng per milliliter and 4 to 7 ng per milliliter, respectively.

\section{TRIAL DESIGN}

This phase 3, multicenter, randomized, open-label trial included patients who had had a first cutaneous squamous-cell carcinoma (TUMORAPA-1, which was registered under ClinicalTrials.gov number NCT00133887 in March 2004 and under EUDRACT 2004-004947-23) and those with multiple squamous-cell carcinomas (TUMORAPA-N, registered under EUDRACT 2005-004509-27). The study was conducted in accordance with the Declaration of Helsinki and Good Clinical Practice guidelines and was approved by the local research ethics committee (TUMORAPA-1 on February 23, 2004, and TUMORAPA-N on June 1, 2004) and the French Health Products Safety Agency. All patients received a detailed description of the study and provided written informed consent. The full study protocol, including the statistical analysis plan, is available with the full text of this article at NEJM.org.

\section{RANDOMIZATION AND TREATMENT}

Patients were randomly assigned in a 1:1 ratio either to transition to sirolimus from calcineurin inhibitors or to continue receiving calcineurin inhibitors. In the sirolimus group, calcineurin inhibitors were discontinued and sirolimus was added to the usual immunosuppressive agents, according to the routine practice of each center (target trough level of sirolimus, 6 to 12 ng per milliliter). The conversion to sirolimus was considered 


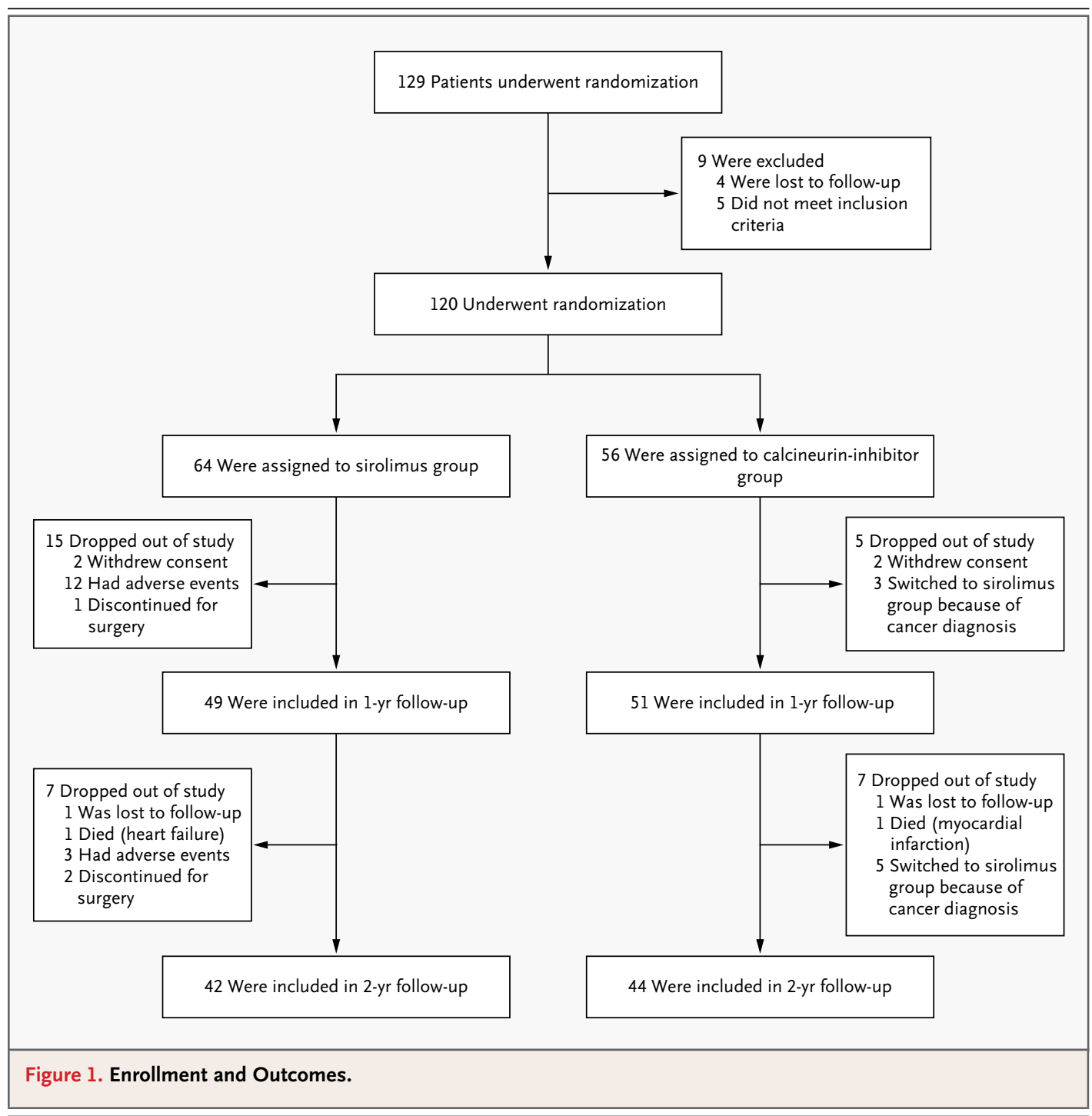

to be rapid if calcineurin inhibitors were discontinued within 7 days and progressive if the conversion took longer than 7 days. In the calcineurininhibitor group, cyclosporine and tacrolimus were maintained at their previous target trough levels.

\section{STUDY EVALUATIONS}

All patients were examined by a dermatologist and a nephrologist at enrollment and every 3 months thereafter until the 2-year mark. During the dermatologic examination, investigators recorded skin type according to Fitzpatrick's classification (Table 1 in the Supplementary Appendix, available at NEJM.org), eye and hair color, and sun exposure. Sun exposure was scored on the basis of occupational and leisure exposure (1, low; 2 , medium; and 3, high), tanning-bed use (1, never; 2 , occasional; and 3, regular), and residence of more than 6 months in a tropical area (1, no; and 2, yes). All histologically determined skin tumors (including squamous- and basal-cell carcinoma, keratoacanthoma, Bowen's disease, premalignant keratosis, and other rare cancers) before and after randomization were counted. Sun-protection advice was provided and its importance was emphasized.

During visits to the nephrology or transplantation clinic at each center, doses of immunosuppressive medications were recorded, along with the patient's history of acute organ rejection. For patients who had undergone more than one transplantation, the duration of immunosuppression was calculated by summing the number of months 
of receipt of immunosuppressive drugs from the first transplantation and subtracting the intervening duration of dialysis. At the initial nephrology visit, measurements of serum creatinine levels, 24-hour protein excretion, and sirolimus or calcineurin-inhibitor levels were obtained; these measurements were then repeated every 3 months in the calcineurin-inhibitor group. In the sirolimus group, monitoring was carried out weekly during the first 2 weeks, monthly during the first 3 months, and then every 3 months.

\section{END POINTS}

The primary end point was survival free of new cutaneous squamous-cell carcinoma at 2 years.
Secondary end points included the time until the onset of new cutaneous squamous-cell carcinoma, occurrence of other skin and nonskin tumors, and graft function. Safety was monitored by means of physical examination, the recording of adverse events, and changes in laboratory measurements.

\section{STUDY OVERSIGHT}

The manufacturer of sirolimus, Pfizer (formerly Wyeth), provided a research grant but had no role in the trial design or in the collection, analysis, or interpretation of the data or writing of the report. The study was sponsored by the Hospices Civils de Lyon, and grants were received from the French Ministry of Health, the French Society of

\begin{tabular}{|c|c|c|}
\hline Characteristic & $\begin{array}{l}\text { Sirolimus } \\
(N=64)\end{array}$ & $\begin{array}{l}\text { Calcineurin Inhibitor } \\
\qquad(\mathrm{N}=56)\end{array}$ \\
\hline Male sex - no. (\%) & $47(73)$ & $45(80)$ \\
\hline \multicolumn{3}{|l|}{ Age at inclusion $-y r$} \\
\hline Median & 62 & 63 \\
\hline Range & $37-84$ & $30-76$ \\
\hline \multicolumn{3}{|l|}{ Skin type - no. (\%) $\dagger$} \\
\hline I, II, or III & $47(73)$ & $46(82)$ \\
\hline IV & $17(27)$ & $10(18)$ \\
\hline \multicolumn{3}{|l|}{ Eye color - no. (\%) } \\
\hline Black or brown & $17(27)$ & $10(18)$ \\
\hline Hazel or light & $47(73)$ & $46(82)$ \\
\hline \multicolumn{3}{|l|}{ Hair color - no. (\%) } \\
\hline Black & $18(28)$ & $14(25)$ \\
\hline Brown & $28(44)$ & $27(48)$ \\
\hline Blond & $15(23)$ & $12(21)$ \\
\hline Red & $3(5)$ & $3(5)$ \\
\hline \multicolumn{3}{|l|}{ Patients with cutaneous squamous-cell carcinoma } \\
\hline Single lesion — no. (\%) & $35(55)$ & $31(55)$ \\
\hline Multiple lesions — no. (\%) & $29(45)$ & $25(45)$ \\
\hline Median - no. & 3 & 3 \\
\hline Range - no. & $2-15$ & $2-12$ \\
\hline \multicolumn{3}{|c|}{$\begin{array}{l}\text { Interval between diagnosis of the most recent cutaneous squamous-cell } \\
\text { carcinoma and randomization - mo }\end{array}$} \\
\hline Median & 4.5 & 6.0 \\
\hline Range & $0-43.5$ & $0-111.1$ \\
\hline Other nonmelanoma skin cancer — no./total no. (\%) & $39 / 63(62)$ & $41 / 55(75)$ \\
\hline \multicolumn{3}{|l|}{ Sun-exposure score } \\
\hline Median & 7 & 7 \\
\hline Range & $4-10$ & $4-10$ \\
\hline
\end{tabular}




\begin{tabular}{|c|c|c|}
\hline \multicolumn{3}{|l|}{ Table 1. (Continued.) } \\
\hline Characteristic & $\begin{array}{l}\text { Sirolimus } \\
(\mathrm{N}=64)\end{array}$ & $\begin{array}{l}\text { Calcineurin Inhibitor } \\
\qquad(N=56)\end{array}$ \\
\hline \multicolumn{3}{|l|}{ Transplantations before randomization — no. (\%) } \\
\hline 1 & $48(75)$ & $48(86)$ \\
\hline$\geq 2$ & $16(25)$ & $8(14)$ \\
\hline Dialysis before transplantation — no. (\%) & $57(89)$ & $52(93)$ \\
\hline History of acute organ rejection — no./total no. (\%) & $15 / 61(25)$ & $12 / 54(22)$ \\
\hline \multicolumn{3}{|l|}{ Length of immunosuppression - mo } \\
\hline Median & 148.6 & 142.9 \\
\hline Range & $18.8-565.6$ & $12.2-426.5$ \\
\hline \multicolumn{3}{|l|}{ Creatinine $-\mu \mathrm{mol} /$ liter } \\
\hline Median & 123 & 116 \\
\hline Range & $61-237$ & 74-241 \\
\hline \multicolumn{3}{|l|}{ Estimated glomerular filtration rate $-\mathrm{ml} / \mathrm{min} \mathbb{S}$} \\
\hline Median & 52.8 & 50.6 \\
\hline Range & $27.3-135.5$ & $31.9-111.2$ \\
\hline \multicolumn{3}{|l|}{ 24-Hr protein excretion $-\mathrm{g}$} \\
\hline Median & 0.10 & 0.10 \\
\hline Range & $0-0.98$ & $0-0.73$ \\
\hline \multicolumn{3}{|c|}{$\begin{array}{l}\text { There were no significant differences between the two study groups. Percentages may not total } 100 \text { because of rounding. } \\
\text { To convert the values for creatinine to milligrams per deciliter, divide by } 88.4 \text {. } \\
\text { Skin type was graded according to Fitzpatrick's classification as follows: type I, white with history of always burning and } \\
\text { never tanning; type II, white with some burning and tanning with difficulty; type III, beige with occasional burning and } \\
\text { gradual tanning to light brown; and type IV, beige with rare burning and tanning to moderate brown. } \\
\text { Sun exposure was scored on the basis of occupational and leisure exposure (1, low; } 2 \text {, medium; and 3, high), tanning-bed } \\
\text { use (1, never; } 2 \text {, occasional; and 3, regular), and residence of more than } 6 \text { months in a tropical area (1, no; and } 2 \text {, yes). } \\
\text { The estimated glomerular filtration rate was calculated by means of the Cockcroft-Gault formula. }\end{array}$} \\
\hline
\end{tabular}

Dermatology, and Pfizer. The first and last authors, along with several colleagues, made the decision to submit the manuscript for publication and vouch for the accuracy and completeness of the data and the fidelity of the study to the protocol.

\section{STATISTICAL ANALYSIS}

Since we used the same methods and end points that were used in both TUMORAPA-1 and TUMORAPA-N, the data were pooled. The analysis included the total population as well as separate analyses of patients who had had a single cutaneous squamous-cell carcinoma and those who had had more than one such lesion before randomization. We used the Mann-Whitney test for comparing quantitative variables and Fisher's exact test for comparing qualitative variables. The main evaluation criteria were analyzed in the intention-to-treat population. We evaluated the status at 2 years for patients who had withdrawn from the study. Deceased patients without cutaneous squamous-cell carcinoma before death were included among patients who were free of cutaneous squamous-cell carcinoma.

Patients were analyzed according to the randomization scheme. We used nonparametric maximum-likelihood estimation to analyze the rate of survival free of new cutaneous squamouscell carcinoma on the basis of interval-censored data. ${ }^{21}$ Since the occurrence of a new carcinoma was observed only quarterly because of the timing of visits, the actual time of the event was unknown and survival was computed at time intervals rather than at a precise times (i.e., the interval between the last visit at which no diagnosis of cutaneous squamous-cell carcinoma was made and the visit when the cutaneous squamous-cell carcinoma was first mentioned). We used the generalized log-rank test to compare the two study groups. ${ }^{21}$ Crude hazard ratios, adjusted haz- 
ard ratios, and tests for interaction were obtained with the use of an accelerated failure-time model with interval censoring. In order to assess the benefit-risk balance, we counted the numbers of cutaneous squamous-cell carcinomas and treatment-related serious adverse events during the therapy period and for 3 months after the discontinuation of treatment. We performed secondary evaluations of patients who completed the 2-year treatment to which they were initially assigned. Analyses were performed with the use of SAS software, version 9.2. A two-sided P value of less than 0.05 was considered to indicate statistical significance.

\section{RESULTS}

\section{PATIENTS}

From March 2004 through March 2009, we enrolled 129 patients in the study; of these patients, 120 were included in the primary analysis (Fig. 1). The demographic characteristics of the patients at baseline were well balanced between the two study groups (Table 1). At baseline, 290 cutaneous squamous-cell carcinomas had been diagnosed in 120 patients; of these patients, $55 \%$ had a single lesion, and the remainder had multiple lesions (average number, 4.2; range, 2 to 15). In addition, $68 \%$ of the patients had a total of 274 other biopsy-proven skin tumors (68 basal-cell carcinomas, 27 keratoacanthomas, 90 in situ carcinomas [or Bowen's disease], and 89 premalignant keratoses). Because of empirical treatments (e.g., cryotherapy), some superficial premalignant lesions were not examined histologically, which may account for the low number of these lesions, as compared with invasive cutaneous squamous-cell carcinomas. A total of 84 patients were receiving cyclosporine, and 36 were receiving tacrolimus, with mean trough levels of $90.6 \pm 33.0 \mathrm{ng}$ per milliliter and $6.9 \pm 2.2$ ng per milliliter, respectively (Table 2 in the Supplementary Appendix).

\section{PRIMARY END POINT}

Survival free of cutaneous squamous-cell carcinoma was significantly longer in the sirolimus group than in the calcineurin-inhibitor group, with a hazard ratio for new carcinoma of 0.37 (95\% confidence interval [CI], 0.16 to 0.85 ) and a study-adjusted hazard ratio of 0.38 (95\% CI, 0.17 to 0.84 ) (Fig. 2A). This difference remained significant for the patients with a single cutaneous squamouscell carcinoma (hazard ratio, 0.03 ; $95 \% \mathrm{CI}, 0.0$ to 0.91 but not for those with more than one cutaneous squamous-cell carcinoma (hazard ratio, 0.67; $95 \%$ CI, 0.29 to 1.54 ) (Fig. 2B and 2C).

The effect of sirolimus was not significantly different between the two studies $(\mathrm{P}=0.054$ for interaction between study and treatment group). Overall, new cutaneous squamous-cell carcinomas developed in 14 patients (22\%) in the sirolimus group and in 22 (39\%) in the calcineurininhibitor group (relative risk, 0.56; 95\% CI, 0.32 to 0.98 ) after a median interval of 15 months, as compared with 7 months $(\mathrm{P}=0.02)$. Among the patients in the sirolimus group who presented with new cutaneous squamous-cell carcinomas, lesions developed in 6 patients after sirolimus withdrawal, with a maximum exposure to sirolimus of 4.1 months. The sex ratio of patients with new lesions was similar to that in the initial population. The clinicopathologic characteristics of new cutaneous squamous-cell carcinomas are shown in Table 3 in the Supplementary Appendix.

Of 86 patients who completed the 2-year treatment, skin cancers that included squamous-cell carcinomas developed in 20 patients (with 71 lesions) in the sirolimus group and in 31 patients (with 191 lesions) in the calcineurin-inhibitor group $(47.6 \%$ vs. $70.5 \%, \mathrm{P}=0.048)$. During the study period, the ratio of squamous-cell carcinoma to basal-cell carcinoma decreased from 3.9 (27 to 7) to 1.4 (11 to 8 ) in the sirolimus group and from 1.8 (21 to 12) to 1.0 (25 to 26 ) in the calcineurin-inhibitor group, as compared with the 2-year period preceding randomization.

Seven patients (including five in the sirolimus group) had a prestudy history of noncutaneous cancer; none of these patients had a relapse during the study. Six noncutaneous cancers were observed in patients with no previous history of solid-organ cancer; two lung cancers had a metastatic course (Table 2).

No episodes of graft rejection occurred during the study (Fig. 1 in the Supplementary Appendix). Trough levels of calcineurin inhibitors and sirolimus remained within the target range of the study (Fig. 2 in the Supplementary Appendix). The average sirolimus levels at 9 months were not significantly higher in patients with new cutaneous squamous-cell carcinomas than those with- 
Figure 2. Probability of Survival Free of New Cutaneous Squamous-Cell Carcinoma at 2 Years.

Shown are probability curves for the primary outcome (survival free of new cutaneous squamous-cell carcinoma) among patients in the intention-to-treat population (Panel A), among those with a single cutaneous squamous-cell carcinoma before randomization (Panel B), and among those with more than one cutaneous squamous-cell carcinoma before randomization (Panel C). The shaded boxes indicate $95 \%$ confidence intervals.

out such lesions (9.66 vs. 8.01 ng per milliliter, $\mathrm{P}=0.08)$. A decrease in or discontinuation of immunosuppressive agents occurred in 15 of 42 patients (36\%) in the sirolimus group and 13 of 44 patients (30\%) in the calcineurin-inhibitor group.

\section{ADVERSE EVENTS}

Almost all sirolimus-treated patients had at least one adverse event that was considered to be related to the study drug (Table 3, and Table 54 in the Supplementary Appendix). Most such events occurred during the first 6 months of the study. A lower sirolimus dose or complementary specific treatments controlled most of them. Adverse events in the sirolimus group led to discontinuations in 15 patients (23\%) after a median of 2.5 months.

Overall, 37 of 64 patients were converted to sirolimus with rapid protocols; these patients had a higher rate of discontinuation than did those who were converted with progressive protocols (11 of 37 patients [30\%] vs. 4 of 27 patients [15\%], $\mathrm{P}=0.24$ ), as well as higher rates of pneumonitis (11 of 37 patients [30\%] vs. 3 of 27 patients [11\%], $\mathrm{P}=0.13$ ) and serious adverse events (24 of 37 patients [65\%] vs. 8 of 27 patients [30\%], $\mathrm{P}=0.01)$.

Metastatic cutaneous squamous-cell carcinoma developed in one patient in the sirolimus group; this patient had received sirolimus for 2 months and was then switched back to calcineurin inhibitors. The metastasis occurred 6 months after the conversion. Eight patients in the calcineurininhibitor group were switched to sirolimus after the development of other cancers (Table 3). Metastatic skin cancers (one case each of squamouscell carcinoma, melanoma, and Merkel-cell carcinoma) developed in three patients.

Among the 120 patients, there were 13 cutaneous squamous-cell carcinomas in 64 patients
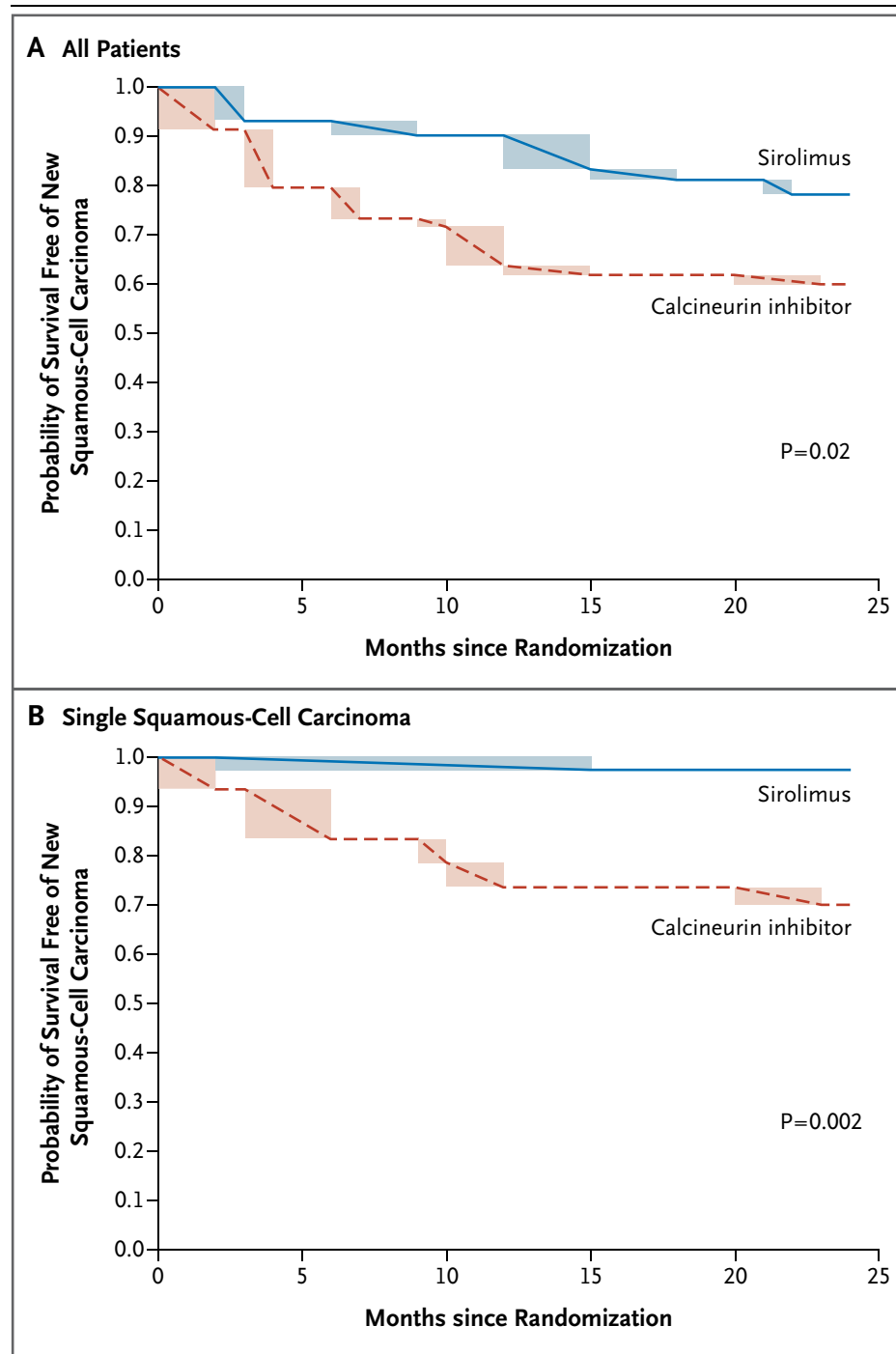

C More Than One Squamous-Cell Carcinoma

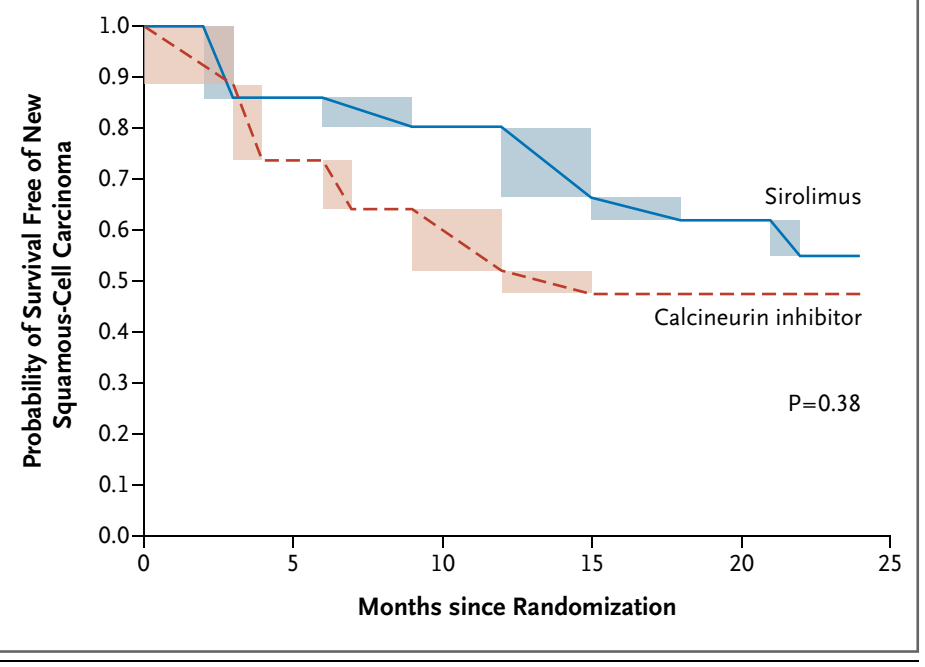




\begin{tabular}{|c|c|c|c|}
\hline Variable & Sirolimus & Calcineurin Inhibitor & P Value ${ }^{-}$ \\
\hline \multicolumn{4}{|l|}{ Secondary outcome } \\
\hline No. of patients evaluated & 42 & 44 & \\
\hline $\begin{array}{l}\text { Patients with at least one new nonmelanoma } \\
\text { skin cancer - no. (\%) }\end{array}$ & $16(38)$ & $28(64)$ & 0.03 \\
\hline $\begin{array}{l}\text { New skin tumors other than squamous-cell } \\
\text { carcinoma }- \text { no. }\end{array}$ & 60 & 164 & \\
\hline Mean & $3.8 \pm 3.6$ & $5.9 \pm 6.5$ & 0.47 \\
\hline Median (range) & $2.5(1-13)$ & $3(1-22)$ & \\
\hline \multicolumn{4}{|l|}{$\begin{array}{c}\text { Patients with a single cutaneous squamous-cell } \\
\text { carcinoma before randomization }\end{array}$} \\
\hline No. of patients evaluated & 24 & 25 & \\
\hline $\begin{array}{l}\text { Patients with at least one new nonmelanoma } \\
\text { skin cancer - no. (\%) }\end{array}$ & $9(38)$ & $15(60)$ & 0.02 \\
\hline $\begin{array}{l}\text { New skin tumors other than squamous-cell } \\
\text { carcinoma }- \text { no. }\end{array}$ & 29 & 53 & \\
\hline Mean & $3.2 \pm 2.8$ & $3.5 \pm 5.5$ & 0.54 \\
\hline Median (range) & $3(1-9)$ & $1(1-22)$ & \\
\hline \multicolumn{4}{|l|}{$\begin{array}{l}\text { Patients with several cutaneous squamous-cell } \\
\text { carcinomas before randomization }\end{array}$} \\
\hline No. of patients evaluated & 18 & 19 & \\
\hline $\begin{array}{l}\text { Patients with at least one new nonmelanoma } \\
\text { skin cancer - no. (\%) }\end{array}$ & 7 (39) & $13(68)$ & 0.10 \\
\hline $\begin{array}{l}\text { New skin tumors other than squamous-cell } \\
\text { carcinoma }- \text { no. }\end{array}$ & 31 & 111 & \\
\hline Mean & $4.4 \pm 4.5$ & $8.5 \pm 6.9$ & 0.15 \\
\hline Median (range) & $2(1-13)$ & $8(1-20)$ & \\
\hline $\begin{array}{c}\text { Incidence of new skin tumors other than } \\
\text { squamous-cell carcinoma }\end{array}$ & 1.43 & 3.73 & \\
\hline No. of patients evaluated & 42 & 44 & \\
\hline At least one basal-cell carcinoma - no. (\%) & $6(14)$ & $12(27)$ & 0.19 \\
\hline At least one keratoacanthoma — no. (\%) & $3(7)$ & $9(20)$ & 0.12 \\
\hline At least one Bowen's disease - no. (\%) & $4(10)$ & $6(14)$ & 0.74 \\
\hline At least one premalignant keratosis — no. (\%) & $11(26)$ & $16(36)$ & 0.36 \\
\hline Other skin cancers - no. & 0 & 1 Merkel-cell, 1 adnexal & \\
\hline Other, nonskin cancers - no. & $\begin{array}{l}1 \text { colon, } 1 \text { prostate, } \\
\text { I lung }\end{array}$ & $\begin{array}{l}\text { I kidney, } 1 \text { lymphoma, } \\
\text { l lung }\end{array}$ & \\
\hline
\end{tabular}

* Plus-minus values are means \pm SD.

$\dagger P$ values were calculated by means of the Mann-Whitney test (for quantitative variables) or Fisher's exact test (for qualitative variables).

† Secondary outcomes were evaluated in 86 patients who completed the 2-year treatment as initially assigned.

(average number, 0.20) in the sirolimus group, as compared with 39 carcinomas in 56 patients (average number, 0.70) in the calcineurin-inhibitor group. In the sirolimus group, there were 60 serious adverse events (average number, 0.94), as compared with 14 (average number, 0.25) in the calcineurin-inhibitor group (Table 3 ).

\section{DISCUSSION}

In this study of kidney-transplant recipients with at least one previous cutaneous squamous-cell carcinoma, switching from calcineurin inhibitors to sirolimus decreased the risk of new cutaneous squamous-cell carcinomas and delayed the 
occurrence of such lesions, as compared with continuing calcineurin inhibitors. Drug discontinuations in the sirolimus group were mainly due to the known adverse effects of the drug. ${ }^{17,22} \mathrm{Al}-$ though serious adverse events were significantly more frequent ( 0.94 per patient) in the sirolimus group than in the calcineurin-inhibitor group $(0.25$ per patient), the number of cutaneous squamouscell carcinomas was lower by a factor of 3.4.

The benefit-risk ratio appeared to increase with lower doses of sirolimus (as compared with higher doses) and with progressive conversion from calcineurin inhibitors to sirolimus (as compared with rapid conversion). This apparent antitumoral effect was more pronounced when sirolimus was introduced after the first occurrence of a cutaneous squamous-cell carcinoma, as compared with introduction after the occurrence of multiple cutaneous squamous-cell carcinomas. Furthermore, the ratio of squamous-cell carcinoma to basal-cell carcinoma decreased substantially in the sirolimus group; a decrease was also observed in the calcineurin-inhibitor group, albeit in a lower proportion of patients, possibly because of the close follow-up, which ensured the removal of premalignant lesions before they became invasive.

All metastases of skin cancers occurred in patients who were receiving calcineurin inhibitors, either initially (in three patients) or after switching back to calcineurin inhibitors after being assigned to the sirolimus group (in one patient). At baseline, the study population was representative of kidney-transplant recipients with a ratio of squamous-cell carcinoma to basal-cell carcinoma of 4 . In addition, the rate of new skin cancers at 2 years in the calcineurin-inhibitor group was similar to that in previous studies., ${ }^{2,3}$

Although we did not observe any significant between-group difference in the rate of noncutaneous cancers, the study was inadequately powered to draw conclusions on this point. Studies that have reported a reduced cancer risk with sirolimus-based immunosuppression that was initiated at the time of transplantation or after early cyclosporine withdrawal have mainly compared regimens with two versus three immunosuppressive agents ${ }^{23}$ or have compared outcomes with registry data. ${ }^{15,16}$ Furthermore, reduced rates of cancer after conversion from calcineurin inhibitors to sirolimus were driven by skin cancers rather than other cancers. ${ }^{17,18}$

We speculate that there may be a specific antineoplastic activity of sirolimus that explains

\begin{tabular}{|c|c|c|c|c|}
\hline \multirow[t]{3}{*}{ Event } & \multicolumn{2}{|c|}{ Adverse Events } & \multicolumn{2}{|c|}{$\begin{array}{l}\text { Serious Adverse } \\
\text { Events }\end{array}$} \\
\hline & $\begin{array}{l}\text { Sirolimus } \\
(N=64)\end{array}$ & $\begin{array}{l}\text { Calcineurin } \\
\text { Inhibitor } \\
(\mathrm{N}=56)\end{array}$ & $\begin{array}{l}\text { Sirolimus } \\
(N=64)\end{array}$ & $\begin{array}{l}\text { Calcineurin } \\
\text { Inhibitor } \\
(\mathrm{N}=56)\end{array}$ \\
\hline & \multicolumn{4}{|c|}{ number of patients } \\
\hline Edema & $37 \dagger$ & 16 & 0 & 0 \\
\hline Acne-like lesions & 28 & 11 & 0 & 0 \\
\hline Aphthous ulcers & $24 \hbar$ & 0 & 0 & 0 \\
\hline Proteinuria & 20 & 4 & 1 & 0 \\
\hline Diarrhea & 17 & 6 & 6 & 1 \\
\hline Dyslipidemia & 15 & 1 & 0 & 0 \\
\hline Pneumonitis & $14 \pi$ & 1 & 13 & 1 \\
\hline Anemia & 12 & 6 & 0 & 0 \\
\hline Cough & 10 & 1 & 0 & 0 \\
\hline Arthralgia & 10 & 9 & 1 & 0 \\
\hline Worsening of hypertension & 9 & 9 & 0 & 0 \\
\hline Leukopenia & 7 & 2 & 0 & 0 \\
\hline Bronchitis & 7 & 3 & 2 & 1 \\
\hline Urinary tract infection & 7 & 4 & 4 & 0 \\
\hline Exercise dyspnea & $6 \dagger$ & 1 & 0 & 0 \\
\hline Unexplained fever & 6 & 1 & 4 & 0 \\
\hline Herpes simplex & 5 & 1 & 2 & 0 \\
\hline Rash & 59 & 0 & 2 & 0 \\
\hline Thrombocytopenia & 5 & 1 & 0 & 0 \\
\hline $\begin{array}{l}\text { Drug discontinuation because } \\
\text { of any adverse event }\end{array}$ & 15 & $8 \|$ & 10 & 3 \\
\hline
\end{tabular}

* Listed are all adverse events that were reported in at least 5 patients. The listed adverse events include serious adverse events. A complete list of serious adverse events (as reported in 32 patients in the sirolimus group and 11 in the calcineurin-inhibitor group) is provided in Table S4 in the Supplementary Appendix. The listed events that were deemed to be related to a study drug were edema, acnelike lesions, aphthous ulcers, proteinuria, diarrhea, dyslipidemia, pneumonitis, anemia, cough, leukopenia, exercise dyspnea, unexplained fever, rash, and thrombocytopenia. Other uncommon study-related events listed in Table S4 were delayed healing, hyperglycemia, and hypokalemia.

$\dagger$ One patient discontinued sirolimus because of this event.

Three patients discontinued sirolimus because of this event.

$\int$ Seven patients discontinued sirolimus because of this event.

I Two patients discontinued sirolimus because of this event.

$\|$ Eight patients crossed over from the calcineurin-inhibitor group to receive sirolimus because of three serious adverse events (kidney cancer, lymphoma, and melanoma in one patient each) and new cutaneous squamous-cell carcinoma (in five patients).

the decrease in new skin cancers rather than a lower amount of immunosuppression. Although no standard criteria exist to compare the levels of immunosuppression of calcineurin inhibitors with those of sirolimus, trough levels were main- 
tained within the study targets. Moreover, equivalent doses of mycophenolate mofetil apparently induced higher drug exposure in patients treated with sirolimus than in those treated with cyclosporine. ${ }^{24}$ Notably, we observed no events related to an overreduction in immunosuppression (mainly rejection) in the sirolimus group.

The effects of mTOR inhibitors have been extensively studied in animal models and assessed in clinical studies both in patients who were not undergoing organ transplantation ${ }^{25,26}$ and in those with cancer. These drugs interrupt the PI3KAKT pathway, which plays a critical role in the regulation of cell proliferation, survival, mobility, and angiogenesis. ${ }^{14}$ Temsirolimus and everolimus are approved for the treatment of metastatic renalcell carcinoma, ${ }^{27,28}$ although at higher doses for everolimus than for the regimens routinely administered after transplantation. ${ }^{29}$ In addition, mTOR inhibitors also inhibit the growth of endothelial cells and the progression of tumor neovascularization at serum concentrations that correspond to the target levels for transplant recipients, both through a decrease of synthesis and a signaling inhibition of vascular endothelial growth factor., ${ }^{9,14}$ The influence of immunosuppressive drugs on skin carcinogenesis induced by ultraviolet radiation (UV) has been assessed in mice. Larger tumors developed in animals that were treated with cyclosporine or tacrolimus than in those treated with sirolimus. ${ }^{30}$ Furthermore, sirolimus had a better effect on the progression of UV-induced tumors than on the initiation of such tumors. ${ }^{31}$ In transplant recipients, sirolimus has been shown to reduce the vascularization and thickness of cutaneous squamous-cell carcinomas. ${ }^{32}$ There is also evidence to suggest that skin carcinomas might be driven by infection with human papillomavirus. ${ }^{33}$ Since the E6 oncoprotein activates the mTOR1 pathway, ${ }^{34}$ we speculate that sirolimus might act on skin cancer through antiviral mechanisms that have been shown with other viruses, such as cytomegalovirus ${ }^{35-37}$ and human herpesvirus $8 . .^{38}$

In conclusion, in this study involving kidneytransplant recipients with at least one previous cutaneous squamous-cell carcinoma, conversion from calcineurin inhibitors to sirolimus was associated with a lower risk of subsequent skin cancers. The data suggest that the earlier the conversion occurs after an initial diagnosis of cutaneous squamous-cell carcinoma, the greater the efficacy.

Supported by Hospices Civils de Lyon and grants from the French Ministry of Health, the French Society of Dermatology, and Pfizer (formerly Wyeth).

Disclosure forms provided by the authors are available with the full text of this article at NEJM.org.

We thank Drs. Nicole Lefrançois and François Chapuis, who were involved in the design of the studies; all the teams who helped to collect data, especially Dr. Nicole Lefrançois, Dr. Jean Louis Bonafé, Dr. Azmi Al Najar, Laurent Villeneuve, and Erica Gaspak; and Kim Barrett for providing editorial assistance.

\section{APPENDIX}

The authors' affiliations are as follows: the Departments of Dermatology (S.E., J.K.) and Nephrology and Transplantation (E.M.), Hospices Civils de Lyon, Edouard Herriot Hospital Group, Lyon; Toulouse University Hospital, Nephrology, Dialysis and Organ Transplant Unit, and INSERM Unité 563, Institut Fédératif de Recherche Bio-Médicale de Toulouse, Toulouse (L.R.); the Department of DermatoCancerology, Hôtel Dieu, Nantes (A.B.); the Departments of Nephrology (V.C.) and Dermatology (A.D.), University Hospital of Caen, Caen; the Department of Nephrology, University Hospital of Nancy, Vandoeuvre-lès-Nancy (M.K.); the Department of Nephrology and Transplantation, Lyon Sud Hospital, Université de Lyon (C.P.-N.) and Pôle Information Médicale Evaluation Recherche, Unité de Recherche Clinique (A.S.R., E.D.), Hospices Civils de Lyon, Lyon; Université de Lyon, Lyon (E.M., A.S.R., E.D.); INSERM Unité 851, Lyon (E.M.); and the Institute of Transplantation, Urology and Nephrology, University Hospital Nantes, Nantes (J.D.) — all in France; the Departments of Nephrology (E.G.) and Dermatology (I.T.), Université Catholique de Louvain, St. Luc University Hospital, and the Departments of Nephrology (N.B.) and Dermatology (V.M.), Erasme Hospital, Université Libre de Bruxelles — all in Brussels; the Departments of Nephrology (A.L.S.) and Dermatology (G.F.L.H.), Zurich University Hospital, Zurich; and the Clinic i Provencal Hospital, Department of Nephrology, Barcelona (J.M.C.).

REFERENCES

1. Euvrard S, Kanitakis J, Claudy A. Skin cancers after organ transplantation. N Engl J Med 2003;348:1681-91.

2. Euvrard S, Kanitakis J, Decullier E, et al. Subsequent skin cancers in kidney and heart transplant recipients after the first squamous cell carcinoma. Transplantation 2006;81:1093-100.

3. Wisgerhof HC, Edelbroek JR, de Fijter JW, et al. Subsequent squamous- and basal- cell carcinomas in kidney-transplant recipients after the first skin cancer: cumulative incidence and risk factors. Transplantation 2010;89:1231-8.

4. Hofbauer GF, Bouwes Bavinck JN, Euvrard S. Organ transplantation and skin cancer: basic problems and new perspectives. Exp Dermatol 2010;19:473-82.

5. Dantal J, Soulillou JP. Immunosuppressive drugs and the risk of cancer after organ transplantation. $\mathrm{N}$ Engl J Med 2005;352:1371-3.

6. Dantal J, Hourmant M, Cantarovich $D$, et al. Effect of long-term immunosuppression in kidney-graft recipients on cancer incidence: randomised comparison of two cyclosporin regimens. Lancet 1998; 351:623-8.

7. Otley CC, Maragh SL. Reduction of immunosuppression for transplant-asso- 
ciated skin cancer: rationale and evidence of efficacy. Dermatol Surg 2005;31:163-8. 8. Ulrich C, Kanitakis J, Stockfleth E, Euvrard S. Skin cancer in organ transplant recipients - where do we stand today? Am J Transplant 2008;8:2192-8.

9. Guba M, Graeb C, Jauch KW, Geissler EK. Pro- and anti-cancer effects of immunosuppressive agents used in organ transplantation. Transplantation 2004;77:177782.

10. Hojo M, Morimoto T, Maluccio M, et al. Cyclosporine induces cancer progression by a cell-autonomous mechanism. Nature 1999;397:530-4.

11. Maluccio M, Sharma V, Lagman M, et al. Tacrolimus enhances transforming growth factor-beta1 expression and promotes tumor progression. Transplantation 2003;76:597-602.

12. Wu X, Nguyen BC, Dziunycz P, et al. Opposing roles for calcineurin and ATF3 in squamous skin cancer. Nature 2010; 465:368-72.

13. Koehl GE, Andrassy J, Guba M, et al. Rapamycin protects allografts from rejection while simultaneously attacking tumors in immunosuppressed mice. Transplantation 2004;77:1319-26.

14. Geissler EK, Schlitt HJ, Thomas G. mTOR, cancer and transplantation. Am J Transplant 2008;8:2212-8.

15. Mathew T, Kreis H, Friend P. Two-yea incidence of malignancy in sirolimustreated renal transplant recipients: results from five multicenter studies. Clin Transplant 2004;18:446-9.

16. Kauffman HM, Cherikh WS, Cheng Y, Hanto DW, Kahan BD. Maintenance immunosuppression with target-of-rapamy cin inhibitors is associated with a reduced incidence of de novo malignancies. Transplantation 2005;80:883-9.

17. Schena FP, Pascoe MD, Alberu J, et al. Conversion from calcineurin inhibitors to sirolimus maintenance therapy in renal allograft recipients: 24-month efficacy and safety results from the CONVERT trial. Transplantation 2009;87:233-42.

18. Alberú J, Pascoe MD, Campistol JM, et al. Lower malignancy rates in renal allograft recipients converted to sirolimusbased, calcineurin inhibitor-free immunotherapy: 24-month results from the
CONVERT trial. Transplantation 2011;92: 303-10.

19. Salgo R, Gossmann J, Schöfer H, et al. Switch to a sirolimus-based immunosuppression in long-term renal transplant recipients: reduced rate of (pre-)malignancies and nonmelanoma skin cancer in a prospective, randomized, assessorblinded, controlled clinical trial. Am J Transplant 2010;10:1385-93.

20. Campbell SB, Walker R, See Tai S, Jiang Q, Russ GR. Randomized controlled trial of sirolimus for renal transplant recipients at high risk for nonmelanoma skin cancer. Am J Transplant 2012;12: 1146-56.

21. Sun J. A non-parametric test for interval-censored failure time data with application to AIDS studies. Stat Med 1996; 15:1387-95.

22. Kreis H, Oberbauer R, Campistol JM, et al. Long-term benefits with sirolimusbased therapy after early cyclosporine withdrawal. J Am Soc Nephrol 2004;15: 809-17.

23. Campistol JM, Eris J, Oberbauer R, et al. Sirolimus therapy after early cyclosporine withdrawal reduces the risk for cancer in adult renal transplantation. J Am Soc Nephrol 2006;17:581-9.

24. Cattaneo D, Merlini S, Zenoni S, et al. Influence of co-medication with sirolimus or cyclosporine on mycophenolic acid pharmacokinetics in kidney transplantation. Am J Transplant 2005;5:2937-44.

25. Serra AL, Poster D, Kistler AD, et al. Sirolimus and kidney growth in autosomal dominant polycystic kidney disease. N Engl J Med 2010;363:820-9.

26. Bissler JJ, McCormack FX, Young LR, et al. Sirolimus for angiomyolipoma in tuberous sclerosis complex or lymphangioleiomyomatosis. N Engl J Med 2008;358: 140-51.

27. Hudes G, Carducci M, Tomczak P, et al. Temsirolimus, interferon alfa, or both for advanced renal-cell carcinoma. $\mathrm{N}$ Engl J Med 2007;356:2271-81.

28. Motzer RJ, Escudier B, Oudard S, et al. Efficacy of everolimus in advanced renal cell carcinoma: a double-blind, randomised, placebo-controlled phase III trial. Lancet 2008;372:449-56.

29. Budde K, Becker T, Arns W, et al.
Everolimus-based, calcineurin-inhibitorfree regimen in recipients of de-novo kidney transplants: an open-label, randomised, controlled trial. Lancet 2011; 377:837-47.

30. Duncan FJ, Wulff BC, Tober KL, et al. Clinically relevant immunosuppressants influence UVB-induced tumor size through effects on inflammation and angiogenesis. Am J Transplant 2007;7:2693703.

31. de Gruijl FR, Koehl GE, Voskamp P, et al. Early and late effects of the immunosuppressants rapamycin and mycophenolate mofetil on UV carcinogenesis. Int J Cancer 2010;127:796-804.

32. Rival-Tringali AL, Euvrard S, Decullier E, Claudy A, Faure M, Kanitakis J. Conversion from calcineurin inhibitors to sirolimus reduces vascularization and thickness of post-transplant cutaneous squamous cell carcinomas. Anticancer Res 2009;29:1927-32.

33. Proby CM, Harwood CA, Neale RE, et al. A case-control study of betapapillomavirus infection and cutaneous squamous cell carcinoma in organ transplant recipients. Am J Transplant 2011;11:1498-508.

34. Spangle JM, Münger K. The human papillomavirus type 16 E6 oncoprotein activates mTORC1 signaling and increases protein synthesis. J Virol 2010;84:9398407.

35. Brennan DC, Legendre C, Patel D, et al. Cytomegalovirus incidence between everolimus versus mycophenolate in de novo renal transplants: pooled analysis of three clinical trials. Am J Transplant 2011:11:2453-62.

36. Moorman NJ, Shenk T. Rapamycinresistant mTORC1 kinase activity is required for herpesvirus replication. J Virol 2010;84:5260-9.

37. Clippinger AJ, Maguire TG, Alwine JC. The changing role of mTOR kinase in the maintenance of protein synthesis during human cytomegalovirus infection. J Virol 2011;85:3930-9.

38. Nichols LA, Adang LA, Kedes DH. Rapamycin blocks production of KSHV/ HHV8: insights into the anti-tumor activity of an immunosuppressant drug. PLoS One 2011;6(1):e14535.

Copyright (c) 2012 Massachusetts Medical Society.

RECEIVE THE JOURNAL'S TABLE OF CONTENTS EACH WEEK BY E-MAIL

To receive the table of contents of the Journal by e-mail every Wednesday evening, sign up at NEJM.org. 